\title{
Gezamenlijke \\ besluitvorming botst \\ met protocollaire zorg
}

\begin{abstract}
Gezamenlijke besluitvorming vraagt van prakijkondersteuners om zich te ontwikkelen van adviseur tot coach. Praktijkondersteuners vinden deze transitie lastig, zo blijkt uit Nederlands onderzoek. Zij hebben behoefte aan meer steun, ook van hun werkgever.
\end{abstract}

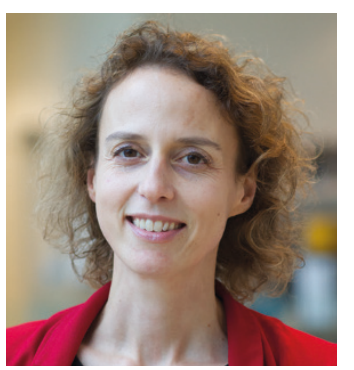

I) Lidewij Broekhuizen Redactielid TPO De Praktijk en huisarts

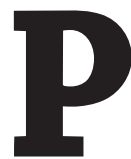
raktijkondersteuners leggen zich toe op gezamenlijke besluitvorming bij het behandelen van patiënten met chronische aandoeningen. De gedachte daarachter is dat dit de motivatie voor gedragsverandering vergroot. In de praktijk blijkt deze aanpak echter soms lastig. Daarom hebben Maastrichtse onderzoekers een methode ontwikkeld om praktijkondersteuners te helpen bij gezamenlijke besluitvorming in hun zorg voor patiënten met astma, COPD en harten vaatziekten.

\section{Onderzoeksopzet}

Aan het onderzoek deden 15 praktijkondersteuners mee. Zij kregen training in gezamenlijke besluitvorming, doelen stellen, acties in gang zetten en behoeftes van de patiënt exploreren. De praktijkondersteuners vulden vragenlijsten in over hun ervaringen in de praktijk, namen consulten op band op en werden geïnterviewd over hun ervaringen.

\section{Resultaten}

De praktijkondersteuners waardeerden de nascholing en merkten dat ze door de hulpmiddelen meer diepgang kregen in de gesprekken met de patiënt. Ze kregen inzicht in hun eigen houding en leerbehoefte. Ze vonden echter ook dat de aanpak botste met de geprotocolleerde aanpak in de huisartsenpraktijk, door de verplichte indicatoren en tijdsdruk. De methode was hierdoor niet goed te integreren in de praktijk. De auteurs concluderen dan ook dat voor implementatie aanpassing van de hele organisatie van de huisartsenpraktijk nodig is.

\section{Hoe nu verder?}

Om gezamenlijke besluitvorming werkelijk toe te passen, moet niet alleen de praktijkondersteuner worden getraind, maar moet de hele huisartsenpraktijk zich hieraan committeren.

\section{Literatuur}

Lenzen SA, Daniëls R, Van Bokhoven MA, et al. What makes it so difficult for nurses to coach patients in shared decision making? A process evaluation. Int J Nurs Stud 2017;80:1-11. 